\title{
VIOLENT DEATH IN THE PLOVDIV REGION OF THE REPUBLIC OF BULGARIA DURING THE PERIOD 2008 - 2017
}

\section{Baltov ${ }^{1}$, I. Bivolarski², K. Sapunarova ${ }^{3}$}

Department of Forensic Medicine and Deontology at the Medical University of Plovdiv, Bulgaria ${ }^{1}$ Department of General and Clinical Pathology at the Medical University of Plovdiv, Bulgaria ${ }^{2}$ Department of Hematology and Oncohematology at the Medical University of Plovdiv, Bulgaria ${ }^{3}$

Key words: violent death, murder, suicide, accidents.

Clinical and experimental pathology. Vol.18, №2 (68). P.92-95.

DOI:10.24061/17274338.XVIII.2.68.2019.243

\begin{abstract}
Violence and aggression always accompany people's lives. They are an integral part of our everyday life, as the potential of violence is part of human nature. The drastic, unreasonable aggression we face on a daily basis often leads to crimes with irreversible consequences. The efforts of a large number of organizations are aimed at limiting them.

The objective of the present work is to study the victims of the various violent deaths in the region of Plovdiv during the period 2008 - 2017.

Material and method. The main method used in the study is historical. Papers for 4,162 autopsies carried out in the Department of Forensic Medicine at the SvetiGeorgi EAD University Multiprofile Hospital for Active Treatment during the period 2008 - 2017 were studied. The obtained results were processed by the methods of parametric analyzes.

Results and conclusions. It was found that annually $0.04 \%$ of the area's population dies of violent death. There is three times the risk of violent death among men rather than women. Victims are mostly people of working age. The risk of violent death for the residents of Plovdiv District is greatest during the summer and in winter.
\end{abstract}

\section{НАСИЛЬСТВЕННАЯ СМЕРТЬ В ПЛОВДИВСКОЙ ОБЛАСТИ РЕСПУБЛИКИ БОЛГАРИЯ В ПЕРИОД С 2008 ПО 2017 ГОД}

\section{М. Балтов, И. Биволарский, К. Сапунарова}

Резюме. Насилие и агрессия всегда сопровождают жизнь людей. Они являются неотьемлемой частью нашей повседневной жизни, поскольку потенииал насилия является частью человеческой природы. Резкая, необоснованная агрессия, с которой мы сталкиваемся ежедневно, часто приводят к преступлениям с необратимыми последствиями. Большое количество организаций направляют свои усилия на их ограничения.

Цель работы - изучение случаев насильственньх смертей в регионе Пловдив в период 2008 - 2017 г2.

Материал и метод. Были изучены документы на 4162 вскрытия, проведенных в отделении судебной медицины многопрофильной больнийы активного лечения SvetiGeorgi University EAD в период 2008 - 2017 г2. Полученные результаты были обработаны методами параметрического анализа.

Результаты и выводы. Было установлено, что ежегодно 0,04\% населения этой территории умирает от насильственной смерти. Риск насильственной смерти среди мужчин в три раза выще, чем среди женщин. Жертвы - это в основном люди трудоспособного возраста. Риск насильственной смерти для жителей района Пловдив высокий летом.

\footnotetext{
Ключові слова: насильницька смерть, вбивство, самогубство, нещасні випадки.

Клінічна та експериментальна патологія Т.18, №2 (68). C.92-95.
}

НАСИЛЬНИЦЬКА СМЕРТЬ У ПЛОВДІВСЬКІЙ ОБЛАСТІ РЕСПУБЛІКИ БОЛГАРІЯ В ПЕРІОД 32008 ПО 2017 РІК

\section{М. Балтов, І. Біволярський, К. Сапунарова}

Резюме. Насильство і агресія завжди супроводжують життя людей. Вони є невід'ємною частиною нашого повсякденного життя, оскільки потенціал насильства $є$ частиною людської природи. Різка, необгрунтована агресія, з якою ми стикаємося щзодня, часто призводить до злочинів із незворотними наслідками. Велика кількості організацій спрямовує свої зусилля на їх обмеження.

Мета роботи - вивчення випадків насильницької смерті в Пловдівській області Республіки Болгарія в період з 2008 по 2017 рік.

Матеріал і метод. Була вивчена документація 4162 розтинів жертв, проведених у відділенні судової медииини багатопрофільної лікарні активного лікування SvetiGeorgi University EAD в період 2008 - 2017 рp. Отримані результати були оброблені методами параметричного аналізу.

Результати і висновки. Встановлено, щүо щүорічно 0,04\% населення цүієї території 
вмирає від насильницької смерті. Ризик насильницької смерті серед чоловіків втричі вищий, ніж серед жінок. Жертви - ие переважно люди прачездатного віку. Ризик насильницької смерті для мешканців району Пловдив найвищий влітку.

\section{Introduction}

Violence and aggression always accompany people's lives. They are an integral part of our everyday life, as the potential of violence is part of human nature. The drastic, unreasonable aggression we face on a daily basis often leads to crimes with irreversible consequences. Murders, suicides, road accidents and other unfortunate events annually take many lives and cause pain and suffering to the loved ones of the victims. Worldwide, the number of these victims is increasing, according to data from some world organizations [1 - 7]. Violent death is subject of extensive research in many countries, but in each country the conditions and nature of the crimes are different $[1,3,5]$.

The objective of the present work is to study the victims of the various violent deaths in the region of Plovdiv during the period $2008-2017$.

\section{Material and method}

The main method used in the study is historical. Papers for 4,162 autopsies carried out in the Department of Forensic Medicine at the SvetiGeorgi EAD University

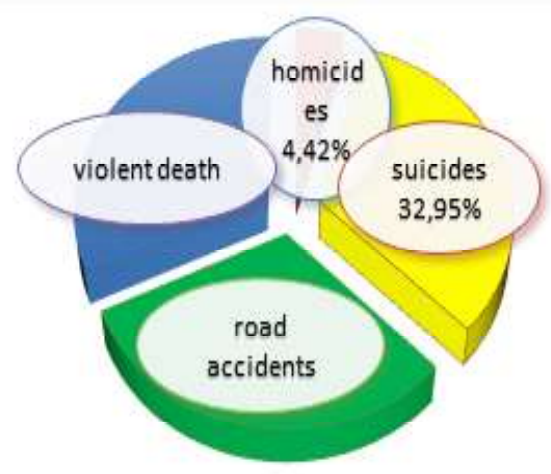

Figure 1. Distribution of victims according to the type of violent death

The dynamics of violent death show a pronounced downward trend. Highest values were recorded during the first three years of the survey period, and the lowest in the last two years.

Victims of violent death are predominantly male - 1,951 $(76.36 \% \pm 0.96 \%)$ and women are $604(23.64 \% \pm 0.84 \%)$. Men dominate in the various types of violent death, but the number of women is the highest in murders and the lowest in accidents (Figure 3 ).

The risk of men losing their life because of murder is nearly twice than that of women. The ratio between men and women who have died because of suicide and accidents is about $3: 1$.

The age at which people most often fall victim to accidents is also studied. The dead people were arranged in four age groups according to their participation in the labor process: children and adolescents up to 18 years of age; young creative age from 19 to 44 years of age; mature
Multiprofile Hospital for Active Treatment during the period 2008 - 2017 were studied. The obtained results were processed by the methods of parametric analyzes [2].

\section{Results and discussion}

During the analysis of the papers, it was found that $2,555(61.39 \% \pm 0.75 \%)$ were victims of violent death. This means that every year 255 people or $0.04 \%$ of the area's population fall victims of various types of violent death. Victims of murder are 113, 842 are suicides, and 1,600 have died in an accident (road accidents, falls from high, labor accidents, freezing, alcohol poisoning, etc.). The relative share of the victims of various types of violent death (Figure 1) shows that the share of victims of accidents is the highestand the share of murdered people is the smallest. This has prompted us to separate the victims of road accidents from the victims of casual accidents. Alarming is the fact that the share of suicides is the highest and exceeds that of people killed in road accidents and othercasula accidents.

The dynamics of violent death over the years is tracked (Figure 2).

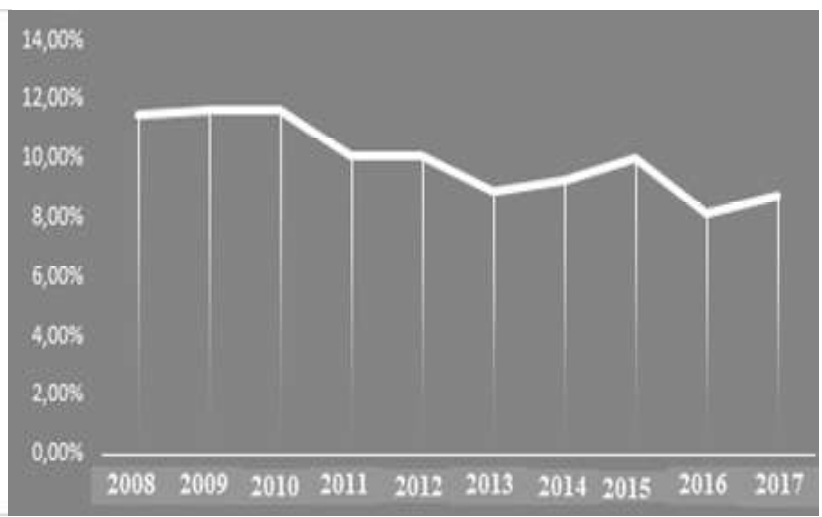

Figure 2. Dynamics of violent death

creative age from 45 to 64 of age and retirement age over 65 (Figure 4).

Children and adolescents most often fall victim to road accidents and other casual accidents, and, most rarely, to suicide. In murders, the highest is the share of retired victims $(32.74 \% \pm 1.37 \%)$. In suicides, the highest is the share of people in mature creative age $(35.99 \% \pm 1.65 \%)$. Young people most often die in road accidents and other casual accidents $(36.38 \% \pm 1.20 \%)$.

The study of the relationship between the annual season and the quantity of violent death showed an approximately uniform distribution (Figure 5).

We established that most murders occurred in the summer $(15.93 \% \pm 3.41 \%)$ and winter $(35.40 \% \pm 4.56 \%)$, and the smallest number in autumn. The cases of suicides are the smallest in autumn $(21.14 \% \pm 1.40 \%)$, and the accidents - in the spring $(22.63 \% \pm 1.05 \%)$. 


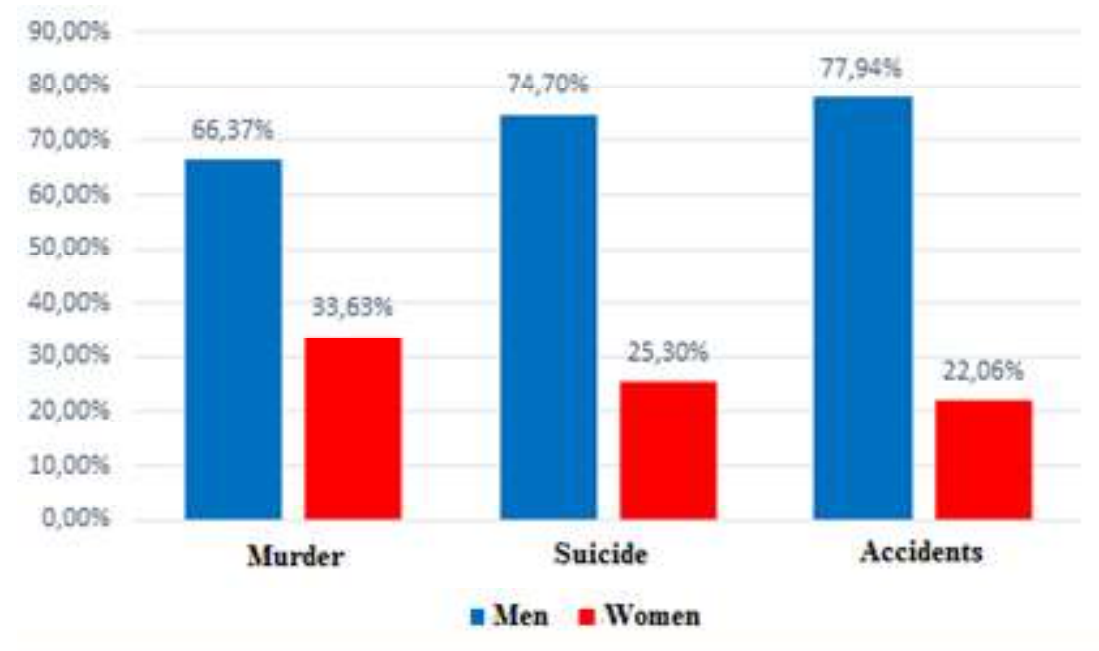

Figure 3. Distribution of the victims of different types of violent death by gender

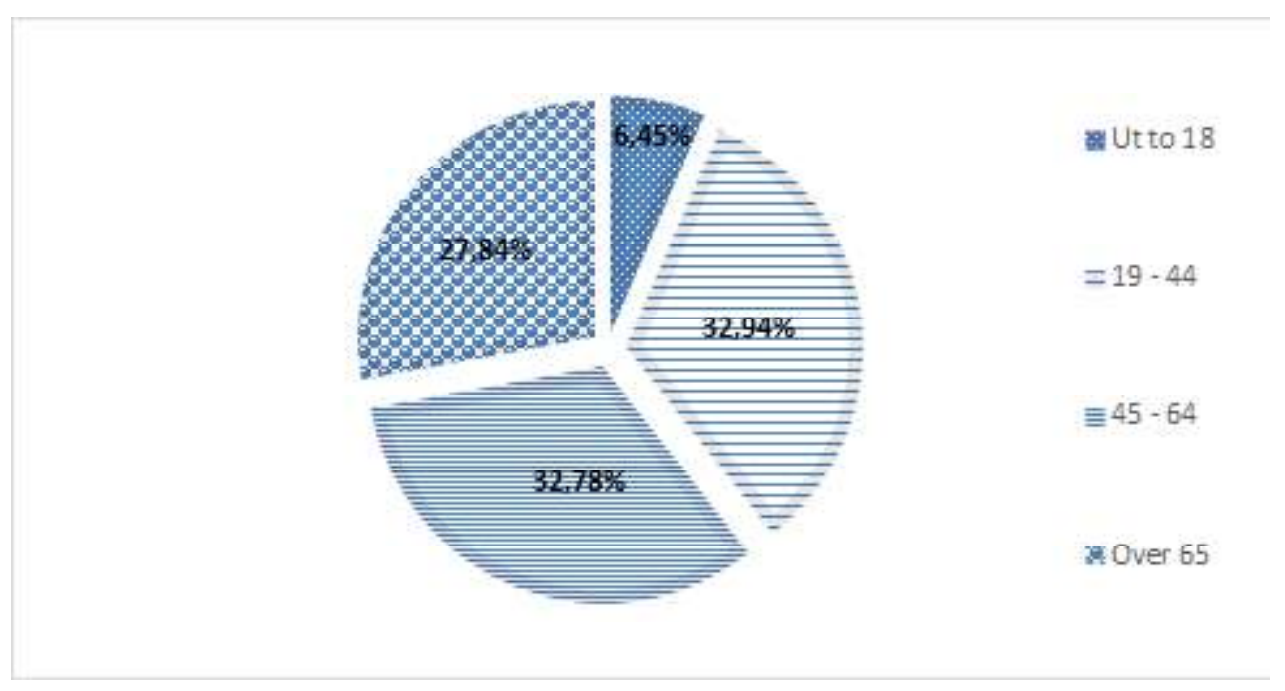

\section{Conclusions}

The results of the 10-year study of violent deaths in the Plovdiv region of the Republic of Bulgaria allowed us to draw the following conclusions:

1. Every year, 255 people or $0.04 \%$ of the population of Plovdiv region are killed by violent death.

2. The dynamics of violent death in the years 2008 2017 show a pronounced downward trend.

3. For men, as well as people in working age, the risk of losing their lives by violent death is increased.

4. The risk of violent death for the residents of Plovdiv District is the highest in the summer and in the winter.

\section{List of literature}

1. Балтов М, Козицька НВ, Гавазда РВ. Порівняльний аналіз та соціально-економічні проблеми самогубств в Пловдівській області (Болгарія) і в Хмельницькій області (Україна). Судовомедична експертиза. 2017;2:62-6.

2. Димитров И. Основи на научните проучвания в медицината: методика и методология. Пловдив: ИК "ВАП"; 2007. 164 c.

3. Йорданова И. Анализ на критичните инциденти със заявено суицидно намерение. Годишник на Института по психология. 2011. 89 с.

4. Advenier AS, Guillard N, Alvarez JC, Martille L, Lorin de la Grandmaison G. Undetermined manner of death: an autopsy series. J Forensic Sci. 2016;61(Suppl 1):S154-8. doi: 10.1111/1556-4029. 12924

ISSN 1727-4338 https://www.bsmu.edu.ua
5.Batton C. Gender differences in lethal violence: Historical trends in the relationship between homicide and suicide rates, 1960-2000. Justice Quarterly. 2004;21(3):423-61. doi: 10.1080/ 07418820400095861

6.Erdogan S, Yalcin M, Yilmaz M, Korkmaz A. Temporal statistic of traffic accidents in Turkey. ISPRS Annals of Photogrammetry, Remote Sensing \& Spatial Information Sciences [Internet]. 2015[cited 2019 Apr 11];2:117-21. Available from: https://www.isprs-ann-photogramm-remote-sens-spatial-inf-sci.net/ II-2-W2/117/2015/isprsannals-II-2-W2-117-2015.pdf

7.Terranova C, Suenghi R, Thiene G, Ferrara S. Psychic trauma as cause of death. Med Sci Law. 2011;51(Suppl 1):S11-5. doi: $10.1258 / \mathrm{msl} .2010 .100061$

\section{References}

1.Baltov M, Kozyts'ka NV, Havazda RV. Porivnial'nyi analiz ta sotsial'no-ekonomichni problemy samohubstv v Plovdivs'kii oblasti (Bolhariia) i v Khmel'nyts'kii oblasti (Ukraina) [Comparative analysis and socio-economic suicide problems in the Plovdiv region (Bulgaria) and Khmelnytsky region (Ukraine)]. Sudovo-medychna ekspertyza. 2017;2:62-6. (in Ukrainian).

2.Dimitrov I. Osnovi na nauchnite prouchvaniya $v$ meditsinata: metodika i metodologiya [Basics of Scientific Research in Medicine: Methodology and Methodology]. Plovdiv: IK "VAP"; 2007. 164 p. (in Bulgarian).

3. Jordanova I. Analiz na kritichnite intsidenti sis zajaveno suitsidno namerenie [Analysis of critical incidents with declared suicidal intent]. Godishnik na Instituta po psikhologiya. 2011. 89 p. (in Bulgarian).

4. Advenier AS, Guillard N, Alvarez JC, Martille L, Lorin de la Клінічна та експериментальна патологія. 2019. Т.18, №2 (68) 
Grandmaison G. Undetermined manner of death: an autopsy series. J Forensic Sci. 2016;61(Suppl 1):S154-8. doi: 10.1111/1556-4029. 12924

5.Batton C. Gender differences in lethal violence: Historical trends in the relationship between homicide and suicide rates, 1960-2000. Justice Quarterly. 2004;21(3):423-61. doi: 10.1080 07418820400095861

6.Erdogan S, Yalcin M, Yilmaz M, Korkmaz A. Temporal statistic of traffic accidents in Turkey. ISPRS Annals of Photogrammetry, Remote Sensing \& Spatial Information Sciences [Internet]. 2015[cited 2019 Apr 11];2:117-21. Available from: https://www.isprs-ann-photogramm-remote-sens-spatial-inf-sci.net/ II-2-W2/117/2015/isprsannals-II-2-W2-117-2015.pdf

7.Terranova C, Suenghi R, Thiene G, Ferrara S. Psychic trauma as cause of death. Med Sci Law. 2011;51(Suppl 1):S11-5. doi: 10. $1258 / \mathrm{msl} .2010 .100061$

\section{Information about authors:}

Baltov M. - PhD, Chief Assistant - Department of Forensic Medicine and Deontology,Faculty of Medicine, Medical University of Plovdiv, Bulgaria

Bivolarski I. - PhD, Assistant - Department of General and Clinical Pathology,Faculty of Medicine, Medical University of Plovdiv, Bulgaria

Sapunarova K. - Assistant - Division of Hematology, First Department of Internal Medicine, Faculty ofMedicine, Medical University of Plovdiv, Bulgaria

\section{Відомості про авторів:}

Балтов М. - к.мед.н., головний асистент кафедри судової медицини та деонтології, Медичний університет, м. Пловдив, Болгарія

Біволярський І. - к.мед.н., асистент кафедри загальної та клінічної патології, Медичний університет, м. Пловдив, Болгарія Сапунарова К. - асистент відділу гематології, першої кафедри внутрішньої медицини, Медичний університет, м. Пловдив, Болгарія

\section{Сведения об авторах:}

Балтов М. - к.мед.н., главный ассистент кафедры судебной медицины и деонтологии, Медицинский университет, г. Пловдив, Болгария

Биволарский И. - к.мед.н., ассистент кафедры общей и клинической патологии, Медицинский университет, г. Пловдив, Болгария

Сапунарова К. - ассистент отдела гематологии, первой кафедры внутренней медицины, Медицинский университет, г. Пловдив, Болгария 